\title{
PARADIGMA SODOBNE ENERGETSKE VARNOSTI
}

\author{
dr.Vladimir Prebilič, dr. Jelena Juvan
}

Fakulteta za družbene vede Univerze v Ljubljani, Katedra za obramboslovje

Kardeljeva ploščad 5, SI-I000 Ljubljana

e-mail:vladimir.prebilic@fdv.uni-lj.si, jelena.juvan@fdv.uni-lj.si

Izvirni znanstveni članek

COBISS 1.01

DOI: 10.4312/dela.41.2.41-54

\section{Izvleček}

Nove, netradicionalne grožnje varnosti, ki so vse bolj kompleksne in indirektne, so postale velik izziv vsem nacionalnim varnostnim sistemom. Med njimi je tudi vprašanje energetske varnosti. Naraščajoča energetska poraba na eni strani, primanjkovanje resursov za proizvodnjo energije na drugi strani, vodijo v t.i. energetsko odvisnost. Oskrba z energijo je nuja za normalno gospodarsko proizvodnjo in rast, je pomembna za dobrobit narodov ter ima velik vpliv na mnoga druga področja nacionalne varnosti, kot so varnost preskrbe $\mathrm{s}$ hrano in pitno vodo, okoljska varnost in trajnostni razvoj.

Ključne besede: Evropska unija, energetska varnost, naravni viri, poraba, politična geografija, geopolitika

\section{NEW ENERGY SECURITY PARADIGM}

\begin{abstract}
New nonconventional and asymmetric security threats posed a great challenge to all national or collective security systems. Among them is question of energy security. Growing energy consumption on one side and lacking resources for energy production leads more and more into energy dependence. Energy is vital for normal economic production and consequently well-being of nations and has enormous consequences on many other fields of national security like food security, environmental security and sustainable development.
\end{abstract}

Key words: European Union, energy security, natural resources, consumption, political geography, geopolitics 


\section{UVOD}

Vprašanje energetske varnosti v Sloveniji in v Evropski uniji je v zadnjih letih postalo posebej aktualno, predvsem v luči vprašanja zagotavljanja zadostne in nemotene preskrbe z energenti in samozadostnosti. Gradnja plinovoda Južni tok je ena izmed glavnih tem, ki jih je bilo mogoče zaslediti v slovenskem medijskem prostoru v preteklem obdobju. Projekt plinovoda Južni tok, ki naj bi z ruskim zemeljskim plinom prek Črnega morja, Bolgarije, Srbije, Madžarske, Slovenije in Avstrije oskrboval Vzhodno in Srednjo Evropo, je do nedavnega potekal precej gladko. Ruska federacija je v zadnjih letih z vsemi državami, po ozemlju katerih naj bi plinovod potekal, sklenila bilateralne medvladne sporazume, $\mathrm{s}$ katerimi naj bi temu finančno zelo zahtevnemu projektu zagotovili politično varnost. V letu 2013 je Gazprom z vsemi vključenimi državami sklenil tudi investicijske dogovore. Zdelo se je, da na poti do novega plinovoda ni več nobenih ovir.

Zaradi neuspelih pogajanj s potencialnimi dobavitelji je dokončno propadel tudi konkurenčni projekt plinovoda Nabucco, ki je, za razliko od Južnega toka, ves čas užival močno podporo Evropske unije. Plinovod Nabucco so načrtovali tako, da bi povezal vire iz Srednje Azije, Zakavkazja in Bližnjega vzhoda s porabniki na Balkanu in v Srednji Evropi. Plinovod Nabucco bi povezal vzhod Turčije s plinskim vozliščem Baumgarten blizu Dunaja v Avstriji, z odcepi do porabnikov zemeljskega plina ob poti (Azerbajdžan odločilen ..., 2014).

Decembra 2013 je Evropska komisija sporočila, da dvostranski sporazumi, ki so jih članice sklenile z Rusijo, niso skladni z evropsko zakonodajo (Gazprom presenečen ..., 2013). Celoten projekt Južnega toka je bil tako postavljen pod vprašaj in časovno zamaknjen. Po mnenju Evropske komisije je sporno, da sporazumi ne upoštevajo načela ločenosti proizvodnje in distribucije plina, saj naj bi plinovod upravljal sam Gazprom. Tudi ni omogočeno sodelovanje tretjih strani pri plinovodu, saj v obstoječih sporazumih piše, da je to plinovod za ruski plin. Sporno naj bi bilo tudi določanje cen oziroma dajatev, za kar naj bi bil pristojen Gazprom, medtem ko evropska zakonodaja določa, da cene predlaga neodvisni upravitelj, potrdi pa jih regulator (Gazprom presenečen ..., 2013). Nekateri analitiki (Zgonik, 2013) menijo, da je opozorilo Evropske komisije o problematičnosti medvladnih sporazumov, ki je sovpadalo z dogodki v Ukrajini, mogoče razumeti tudi kot protiukrep Bruslja v 'nenehni geostrateški igri za prevlado na celini'.

Takšna in podobna dejstva kažejo na izjemno aktualnost energetske varnosti, ki jo moramo razumeti v širšem kontekstu pomensko širšega vprašanja nacionalne varnosti, saj oskrba z energijo še nikoli prej ni bila tako pomembna kot je v sodobni družbi. Razlog je v globoki energetski odvisnosti skoraj vseh družbenih sistemov, zato tudi ne presenečajo podatki o nenehnem naraščanju porabe energije. Posledice tega dejstva se kažejo v ceni energije, te pa direktno ali indirektno vplivajo na finančno obremenitev posameznika. Zato si države prizadevajo zagotoviti čim stabilnejšo, varno in predvsem cenejšo oskrbo z energijo. Ker to vse bolj postaja tudi varnostno vprašanje za večino držav, te redifinirajo svoje geostrateške koncepte, ki v mnogih primerih predvidevajo tudi uporabo sile za vzdrževanje energetske varnosti ter celo oviranje drugih držav pri omenjenih naporih. 
Mogoče je celo prepoznati oborožene konflikte med državami ali znotraj posameznih držav, katerih bistveni cilj je energetska varnost oziroma zagotavljanje bodisi dostopa ali transporta energijskega vira.

Vpliv energetske varnosti na vsakdanje življenje je nedvomno dihotomen. V prvem pogledu gre za vpliv na poslovanje gospodarskih družb, za katere predstavljajo energenti temeljni fiksni strošek, tako v surovinski kakor v proizvodni obliki. S tem se zaradi višjih cen njihovih proizvodov znižuje tržna konkurenčnost podjetij, hkrati pa so podjetja prisiljena $v$ zniževanje stroškov na drugih področjih - praviloma na račun delovne sile. Z zniževanjem kupne moči ljudi pa se krog sklene, saj ima to neposreden učinek na potrošnjo in posledično povpraševanje ter končno na potrebe proizvodnje. V drugem pogledu pa energetsko (ne)varnost občutijo vsi posamezniki v različnih novih podražitvah vseh energentov. Prav to pa je še bolj pomembno v kontekstu prej omenjenega zniževanja kupne moči.

\section{VARNOST KOT VEČDIMENZIONALEN KONCEPT}

Varnost je stanje, o katerem se noben posameznik ne sprašuje, dokler tega stanja ni več. Varnost lahko, podobno kot zdravje, razumemo tudi kot temeljni pogoj človeškega bivanja. Za nemoteno življenje, delovanje in bivanje, človek potrebuje varnost. Če ima posameznik občutek varnosti, lahko kar najbolje deluje kot človeško bitje, ki zadovoljuje potrebe na način, kakršnega si želi oziroma hoče, saj se počuti varnega. Kot najširšo možno opredelitev pojma varnost lahko uporabimo definicijo Grizolda (1992, str. 63), da »varnost lahko opredelimo kot stanje, v katerem je zagotovljen uravnotežen fizični, duhovni in duševni ter gmotni obstoj posameznika in družbene skupnosti v razmerju do drugih posameznikov, družbenih skupnosti in narave «.

Sodobna varnostna paradigma obravnava varnost znotraj treh temeljnih konceptualnih okvirov: kot individualno, nacionalno in mednarodno varnost (Grizold, 1992). Če je posameznikova potreba po varnosti zadovoljena, sta mu omogočena kakovosten obstoj in razvoj. Individualna varnost je vedno relativna. Mednarodna varnost je notranje varnostno vprašanje sistema držav in sveta kot celote; je kolektivna dobrina mednarodne globalne družbe in ne le dobrina posamezne države ali zveze držav. V konceptih individualne in nacionalne varnosti, v katerih je prisotna predpostavka o virih ogrožanja na eni in ogroženem subjektu na drugi strani, pa prihajajo grožnje mednarodni varnosti od znotraj (tj. od drugih držav članic mednarodnega sistema).

Nacionalna varnost se opredeljuje kot »varnost državnega ozemlja, prebivalstva in njegove lastnine, ohranjanje nacionalne suverenosti kot zagotavljanje ustreznih razmer za uresničevanje temeljnih funkcij družbe« (Grizold, 1992, str. 63). Nacionalna varnost sicer res zagotavlja varnost državljanov ter odpravlja vire ogrožanja, toda hkrati prek svojih varnostnih organov tudi sama postane vir ogrožanja individualne varnosti. Povezanost nacionalne varnosti in s tem posledično individualne je utemeljil Grizold (1992, str. 63), poudarjajoč, da je »nacionalna varnost danes politična in osebna dobrina, ki se v razvitih industrijskih državah uresničuje kot temeljna človekova pravica. Zanjo skrbi država, ne samo s sprejemanjem ustrezne zakonodaje, na primer kazenske, temveč tudi 
z angažiranjem celotne nacionalnovarnostne strukture «. Pojma nacionalna in državna varnost se pogosto izenačujeta, zato je treba tudi njuno zvezo vsaj nekoliko pojasniti. Ko govorimo o državni varnosti, ima beseda varnost dva pomena, prvič kot stanje na ravni vse države, torej $\mathrm{v}$ pomenu nacionalne varnosti, in pomen 'varnostništva' kot skupka dejavnosti, s katerimi država zagotavlja varnost na ravni celotne družbe (Grizold, 2001, str. 130).

V preteklosti se je pri pojmu varnost praviloma pomislilo zgolj na zagotavljanje varnosti z uporabo vojaških sredstev, medtem ko se v sodobnosti vse bolj uveljavljajo tudi drugi mehanizmi in instrumenti preprečevanja pojavljanja vzrokov ogrožanja varnosti. Razloge za sodobnejše, večdimenzionalno dojemanje varnosti je mogoče iskati tudi v spremembah širšega mednarodnega okolja v osemdesetih letih 20. st., ki so zaradi naftne krize, svetovne inflacije, denarne nestabilnosti, nezaposlenosti ipd., privedle do oblikovanja novih pogledov in novih spoznanj. S tem je družba prerasla ozko tradicionalistično pojmovanje varnosti, ki je obsegalo zgolj vojaško dimenzijo varnosti. Ta je zaradi preteče nevarnosti oboroženega spopada med dvema velesilama prevladovala v času hladne vojne in je dejansko zožila pogled na druge dimenzije varnosti. Grizold (1991, str. 9) ugotavlja, da je varnost celostni pojav, oziroma pojav z univerzalno vsebino, ter ga je zato zaradi zaznavnih in analitičnih zmožnosti raziskovalcev skorajda nemogoče teoretično obvladovati kot celoto v vsej njegovi razsežnosti oziroma multidimenzionalnosti.

Varnost je pogoj za razvoj kogar koli in česar koli. Brez nje ni moč pričakovati napredka, saj smo ljudje že zdavnaj spoznali, da je to ena najpomembnejših vrednot in omogoča uresničevanje večine drugih vrednot, zaradi česar jo problematizirajo prenekatere družbene znanosti, kot so pravo, sociologija, ekonomija in druge (Žnidarič, 2006, str. 21).

\section{TEORIJA ENERGETSKEVARNOSTI}

Pri razpravi o energetski varnosti se moramo najprej vprašati, kaj energetska varnost sploh je in kaj vključuje. Evropska komisija in Mednarodna agencija za energijo opredeljujeta energetsko varnost kot »zagotavljanje cenovno zmerne, zanesljive in okolju prijazne preskrbe z energijo « (Müller-Kraenner, 2007, str. xi). Vendar ta opredelitev odpira nekaj dodatnih vprašanj: Kaj sploh je zanesljiva preskrba? Kako presojamo, kaj je cenovno zmerno? Politične in ekonomske razprave zadnjih let, ki se vrtijo predvsem okrog iskanja odgovorov na ti dve vprašanji, so vplivale tudi na preoblikovanje svetovnega razmerja moči »ne skladno s tem, kdo nam je všeč, ampak kdo poseduje, kar mi potrebujemo« (Müller-Kraenner, 2007, str. xi). Najmočnejše države tako postajajo tiste, ki nadzorujejo še razpoložljive energijske vire in imajo dostop do svetovnega trga teh virov. In tako so te države postale 'novi akterji'1 v globalni geopolitični arhitekturi in določajo nova razmerja, ki jim morajo druge, energetsko nepreskrbljene in

1 Müller-Kraenner (2007, str. xi) ugotavlja, da so Evropska unija, Rusija in Kitajska tisti novi akterji, ki skupaj z ZDA tekmujejo na globalnem trgu 21. st., za razliko od 19. st., ko sta Rusija in Velika Britanija tekmovali za nadzor nad Srednjo Azijo. Današnja igra ni samo prerivanje za politična in gospodarska vplivna območja, ampak tudi za opredelitev pravil na energetskih trgih. 
posledično energetsko odvisne države upoštevati. V sodobnem svetu je mogoče identificirati predvsem dve nasprotujoči si politiki: na eni strani novo politiko moči, po kateri so ZDA prevzele temeljito vojaško in politično rekonstrukcijo Bližnjega vzhoda, medtem ko Ruska federacija ${ }^{2}$ in Ljudska republika Kitajska ${ }^{3}$ skozi energetska podjetja v državni lasti zasledujeta ekspanzivno politiko, in na drugi strani politiko, ki se osredotoča na varstvo okolja, varčevanje z energijo, obnovljive vire in mednarodno sodelovanje (Müller-Kraenner, 2007, str. xi). Nemalokrat sta si prva in druga politika $\mathrm{v}$ nasprotju, hkrati pa je postalo jasno, da je potrebno nadgraditi temeljne nosilce moči države in posledično njen vpliv na področju energetske varnosti.

Zato ni nenavadno, da je energetska varnost države eden izmed sestavnih delov nacionalne varnosti. $\mathrm{V}$ tesni povezavi s pojmom energetska varnost se uporablja pojem energetska samozadostnost oziroma energetska (so)odvisnost. Zelo pogosto je moč zaslediti trditve, da bodo v prihodnosti oboroženi konflikti potekali zaradi (energetskih) virov. Če pogledamo zemljevid sveta, lahko ugotovimo, da so energetsko najbogatejši deli sveta istočasno tudi najbolj konfliktni. Nekateri avtorji pa $\mathrm{v}$ energetskih virih prepoznavajo razloge za nove vojne, ki bodo vojne za vire.

Danes nobena visoko industrializirana družba ne more preživeti brez oskrbe z nafto, zato vsaka resna grožnja o prekinitvi oskrbe s tem virom (lahko) predstavlja vzrok za krizo, v skrajnih primerih je lahko tudi povod za uporabo vojaške sile. Vsi spori, veliki in majhni, ki so kakorkoli povezani z nafto, v prihodnosti predstavljajo pomemben element v globalnem varnostnem okolju (Klare, 2003, str. 27). To ne preseneča, saj je energetska (ne)varnost neposredno povezana z gospodarsko (ne)stabilnostjo, kar je v razmerah poglobljene gospodarske krize, oziroma v nekaterih državah že recesije, izjemen destabilizacijski moment celotne družbe. Reševanje in predvsem strateško načrtovanje na področju energetike dokazljivo vodita $\mathrm{v}$ zagotavljanje energetske varnosti ter ustvarjanje pozitivnega gospodarskega okolja. Smotrno in racionalno upravljanje s tveganji na energetskem področju lahko energetske izzive spremeni v vire razvoja in reševanja (pre)mnogih okoljskih vprašanj ${ }^{4}$, povezanih s posledicami energetskega obremenjevanja. Zato vsa gospodarstva in tržišča svetovnih sil tako zelo občutljivo reagirajo na vsak nov

2 Ruska federacija je pomemben akter v preskrbi z energijo tako za EU kot tudi za Azijo. Dandanes se njena nova politika moči »... osredotoča na moč Gazproma in ne na vojaško moč Rdeče armade« (MüllerKraenner, 2007, str. xii).

3 Müller-Kraenner (2007, str. xii) identificira še en problem, povezan s svetovno energetsko preskrbo. Večina svetovnih energetskih zalog se nahaja pod morsko gladino. Države se medsebojno borijo za suverenost in pristojnost nad temi območji, kar povzroča dodatne napetosti v mednarodnih odnosih med LR Kitajsko in drugimi državami. Poleg tega pa »... kitajska državna naftna podjetja zelo agresivno nastopajo na svetovnih trgih, ne upoštevajoč okoljevarstvene standarde in spoštovanje človekovih pravic« (Müller-Kraenner, 2007, str. xii). Lahko ugotovimo, da se v boju za energetsko prevlado uporabljajo vsa razpoložljiva sredstva, ne glede na posledice.

4 Začetek 20. st. je zgodovinski mejnik, tudi zaradi povečane porabe pitne vode, lesa in mineralov ter večje industrijske proizvodnje. Omenjene spremembe so vzrok za naraščanje količin trdih odpadkov ter povečano onesnaženost zraka in vode (McNeill, 2001, str. 17). Svetovno povpraševanje po energiji bo še naprej naraščalo - do leta 2030 za dodatnih $60 \%$. Samo povpraševanje po nafti se bo povečevalo za 1,6 \% na leto (Potencialni ukrepi ..., 2013). 
oborožen konflikt ali vojno. ${ }^{5}$ To je nedvomno še en dokaz globalne povezanosti sveta ter tudi naraščajočega pomena energetske varnosti.

Tudi EU in vse njene institucije se vedno bolj zavedajo pomena energetske varnosti. Zato je Evropska komisija temu vprašanju posvetila več pozornosti in sicer že predstavljeno definicijo energetske varnosti nadgradila še z dvema vidikoma: energetska oskrba mora biti utemeljena na principu trajnosti in biti dostopna za vse (Resolucija Evropskega parlamenta .., 2013). Sovacool (2011, str. 8-9) tako izpostavlja in združuje omenjene značilnosti energetske varnosti v štiri najbolj bistvene elemente: razpoložljivost, zanesljivost, cenovna dostopnost in trajnost.

Razpoložljivost je možnost dostopa vseh potrošnikov energije do zadostnih količin le-te. To omogočajo veliki in razviti trgi, kjer potrošniki lahko kupujejo, ponudniki pa prodajajo energijo in kjer so postavljeni sprejemljivi pogoji. Predpogoj je zadostna količina energije, za kar mora biti zagotovljena ustrezna infrastruktura in potrebne investicije vanjo ter tehnologije, ki omogočajo prodajno-nakupni proces. Bistveni so še pravni okvir in regulatorji, ki vse te procese na trgu nadzirajo in podpirajo. Zanesljivost pomeni izločitev različnih motenj v dobavi, kar je mogoče zgolj z raznolikostjo virov v ponudbi (različnih energentov in tudi tehnologij), razvejenost oskrbovalnih poti (prekinitev ene od njih ne pomeni motnje v oskrbi), sposobnost obvladovanja motenj, zmanjševanje energetskih potreb (nove in boljše tehnologije itd.) z namenom razbremenitve infrastrukture, hitro okrevanje in ponovne vzpostavitve sistema v primeru napak ter zagotavljanje pravočasnih in točnih informacij. Cenovna dostopnost vsebuje tako ustrezno nizke oziroma pravične cene glede na dohodke, kot tudi stabilne cene, ki so stanovitne in ne nihajo, predvsem pa so potrošniki o spremembah pravočasno, zadostno in argumentirano obveščeni. Trajnost pomeni minimaliziranje oziroma zagotavljanje čim nižje socialne, okoljevarstvene in ekonomske škode, ki je lahko posledica energetske infrastrukture (onesnaževanje, ki vpliva tako na okolje kot tudi na zdravje ljudi; Sovacool, 2011, str. 9).

Ob tem ne smemo pozabiti na multidimenzionalnost pojma energetska varnost. Baumann (2008, str. 4-5) definira štiri glavne dimenzije energetske varnosti, ki se medsebojno prekrivajo in hkrati dopolnjujejo: dimenzija notranje politike, ekonomska dimenzija, geopolitična dimenzija in dimenzija varnostne politike.

Notranje politike se nanašajo predvsem na ustrezno izgradnjo in vzdrževanje energetske infrastrukture, kar preprečuje morebitne motnje v distribuciji energije, krizno načrtovanje, ki povečuje odpornost energetskega sistema v izrednih razmerah (načrtovanje, prioritete oskrbe, nadomestni viri, gospodarjenje z zalogami,...), zagotavljanje energetske učinkovitosti, ki prinaša prihranke pri porabi energije, zmanjšuje obremenitev energetskega sistema ter posledično znižuje energetsko odvisnost, in odločanje o energijskih virih - strateško usmerjanje porabe energije v dostopnejše in čim bolj lokalne vire energije (Baumann, 2008, str. 6-7).

5 Budna in Budna (2013) po drugi strani ugotavljata, da je energetska varnost neposredno povezana $\mathrm{z}$ elementi gospodarske stabilnosti, saj lahko gospodarstvo ob zagotovljeni energetski varnosti dobro deluje in se razvija, ob zmanjšanju le-te pa ima gospodarstvo težave in stagnira ali celo nazaduje, kar vodi v težave na vseh ostalih področjih države, in ne nazadnje lahko ob zelo zaostrenih razmerah vpliva tudi na nacionalno varnost. 
Pri ekonomski dimenziji gre predvsem za naslednje tri elemente: obstoj energetskega trga, mednarodno trgovino z energijo ter tehnologijo. Prvi omogoča cenovno sprejemljivo in zanesljivo dobavo energije, drugi predstavlja možnost zagotavljanja zadostnih količin energije energetsko odvisnim državam, medtem ko morajo tehnološke rešitve prinašati večjo racionalnost pri porabi ter iskati alternativne in okolju prijaznejše rešitve pri ravnanju z energijo (Baumann, 2008, str. 6-7).

Pod geopolitično dimenzijo razumemo oblikovanje transnacionalnih omrežij, ki državam omogočajo uspešnejše zagotavljanje energetske varnosti. Gre predvsem za vzpostavljanje novih razmerij med mednarodnimi korporacijami in državami, predvsem v smislu povečevanja vloge držav. Izkušnje in ravnanja korporacij velikokrat ne omogočajo ali celo sprožajo občutke energetske nevarnosti, saj so od tega posledično odvisne cene energije, kar pa korporacijam predstavlja izvirni dobiček (Baumann, 2008, str. 7).

Dimenzija varnostne politike se nanaša na pripravo načrtov in postopkov, kadar je iz različnih razlogov v nevarnosti energetska infrastruktura (naravne in tehnološke nesreče, napadi terorističnih ali kriminalnih skupin, vojne; Baumann, 2008, str. 6-7).

Na osnovi napisanega, je mogoče priti do naslednjega zaključka: če so vse štiri dimenzije usklajene znotraj posamezne države, slednja ne bi smela imeti težav pri uspešnem zagotavljanju energetske varnosti.

\section{GEOPOLITIKA ENERGETSKEVARNOSTI}

Da bi lažje razumeli vpliv, ki ga ima paradigma energetske varnosti na spremenjeno geopolitiko sveta, je smiselno medsebojno soočiti oba termina. Agnew (1998, str. 128) je opredelil geopolitiko kot »preučevanje vpliva geografskih ločnic in dejavnikov na vodenje svetovne politike. $\mathrm{V}$ prvotnem pomenu in uporabi se je termin nanašal na vpliv meddržavnih odnosov zaradi prostorske razporeditve celin in oceanov in distribucije naravnih in človeških virov«. Cohen pravi, da je geopolitika produkt časa in da so se vse definicije geopolitike s časom spreminjale in razvijale. Tako lahko geopolitiko danes definiramo kot »analizo interakcij med geografskimi danostmi in možnostmi na eni strani in političnimi procesi na drugi strani«(Cohen, 2003, str. 12).

Geografske danosti sestojijo iz geografskih značilnosti in geografskih vzorcev, politične procese pa definirajo tako sile v državah, ki vplivajo na mednarodno politiko, kot tudi sile, ki so prisotne na mednarodni ravni. Enako kot geografske značilnosti vplivajo na politične procese, tudi politični procesi vplivajo na geografske značilnosti. Geopolitika je tako posledica delovanja teh medsebojnih interakcij. Primarno je teorija geopolitike izšla iz geografije, politična znanost jo je začela preučevati šele v nadaljnjem razvoju (Cohen, 2003, str. 12). Dolman (2002, str. 12) je izpostavil, da je geopolitika ena najstarejših in tudi zelo prepoznavnih delov politične teorije. S to trditvijo se lahko strinjamo, saj so geografske značilnosti oziroma dejavniki naravno dani in jih države oziroma vsi mednarodni subjekti težko spreminjajo, lahko pa se jim prilagodijo in jih tako obrnejo sebi v prid. Že najzgodnejše državne tvorbe so težile k temu, da bi naravne danosti karseda najbolje izkoriščale in se tudi širile na račun teh naravnih danosti. 
Za geopolitiko je tako najpomembnejši prostor, v katerem pa se subjekti že vseskozi zavedajo pomena vprašanj v zvezi z energijo oziroma energetiko ter možnosti za izkoriščanje, ki se v tem prostoru nahajajo. To ima za posledico zanimanje subjektov, kar lahko pripelje tudi v konflikte. V spremenjenem političnem okolju je posest nad vojaškimi arzenali nadomestilo lastništvo nad zalogami nafte, zemeljskega plina in drugimi primarnimi energijskimi viri. Kdor poseduje energetske zaloge, 'vlada' svetu. In danes to niso več države, ampak vedno bolj (multi)nacionalne korporacije, ki ustvarjajo enormne dobičke. Tako je ameriška revija Forbes razglasila ruskega energetskega velikana Gazprom za najbolj dobičkonosno podjetje na svetu v letu 2011 (Russia’s Gazprom ..., 2014). Energetski trgi in vprašanja varnosti preskrbe so medsebojno prepleteni dejavniki nove globalne geopolitike, ki zahtevajo energetsko osredotočene zunanje politike (Kalicki, Goldwyn, 2005).

Ravno tako zaskrbljujoča je omejenost energijskih virov oziroma strah, da bodo svetovne zaloge ključnih virov energije (predvsem nafte) enkrat pošle. Vedno več je dokazov, da se obdobje 'zlahka dosegljive nafte' (angl. easy oil) končuje in da se začenja obdobje 'težko dosegljive nafte' (angl. tough oil) (Klare, 2008, str. 13). Po mnenju strokovnjakov bo vsak novi sodček nafte dražji od prejšnjega, nahajal se bo globlje pod zemeljskim površjem, dalj od morske obale, v nevarnejših okoljih in bolj konfliktnih predelih zemeljske oble. Podobne scenarije je mogoče predvideti tudi za druge obstoječe energente, premog, zemeljski plin in uran (Klare, 2008, str. 13). Yergin (2011, str. 3) je identificiral tri ključna vprašanja, povezana s svetovno energetsko preskrbo danes: »Ali trenutne zaloge energije zadostujejo potrebam naraščajočega sveta, s kakšnimi stroški in s katerimi tehnologijami? Kako je mogoče zagotoviti varnost energetskih sistemov, od katerih je svet odvisen? Kakšni bodo učinki okoljevarstvenih skrbi, predvsem glede klimatskih sprememb, na prihodnost energetske preskrbe? «.

Namesto odgovora na ta vprašanja se vse bolj jasno kažejo obrisi posledic. V današnjem energetskem svetovnem redu razlikujemo dve skupini držav: države z energetskim primanjkljajem in države z energetskim presežkom. »V nekdanji svetovni ureditvi je status države v globalni hierarhiji določalo število jedrskih bojnih konic, bojnih ladij in število mož pod orožjem« (Klare, 2003, str. 14). V novi ureditvi bo položaj države vedno bolj določen s količino naftnih in plinskih rezerv ter zmožnostjo države, da za nakup energijskih virov uporabi tudi druga sredstva. Takšna spremenjena svetovna ureditev ima nedvomno tudi očitne gospodarske posledice. »Države z energetskim primanjkljajem, kot npr. Kitajska, Japonska in ZDA, so prisiljene plačevati vedno višjo ceno za energente, medtem ko medsebojno tekmujejo za gospodarsko prevlado« (Klare, 2003, str. 15).

V zadnjih desetletjih se je pod vplivom sprememb v mednarodni skupnosti po koncu hladne vojne ${ }^{6} \mathrm{v}$ razmerje med konceptoma energetske varnosti in geopolitike vedno bolj

6 Baru (2012, str. 50) ugotavlja, da je bil propad Sovjetske zveze sam po sebi najpomembnejši geoekonomski pojav povojnega obdobja. Že dolgo preden je Sovjetska zveza dejansko razpadla, so bile vzpostavljene gospodarske razmere za njen razpad, saj je sovjetsko gospodarstvo začelo izgubljati na moči. 
'vrinjal' novi koncept geoekonomike. ${ }^{7} \gg$ Meddržavne spore in konflikte je potrebno gledati z vidika konkurence tržnih deležev v mednarodni trgovini« (Luttwak, 1999, str. 17). Luttwak to imenuje vstop v t. i. dobo geoekonomike (1999, str. 17). Po njegovem mnenju mednarodni konflikti ustvarjajo gospodarske konfrontacije in spore zaradi distribucije in potrošnje nacionalnih in mednarodnih dobrin. Pojav novega (svetovnega) bojišča privede do uvedbe geoekonomskega orožja, ki ga sestavljajo elementi sistematične podpore s strani posameznih držav v obliki raziskovalnega in razvojnega financiranja, povezano $\mathrm{z}$ donacijami za proizvodne sektorje, kot tudi zagotavljanje posojil z nizkimi obrestmi, poznanimi tudi kot predatorska posojila.

Baru (2012, str. 54-55) identificira štiri dejavnike kot ključne determinante geoekonomske moči države: moč znanja, ki je odvisna od demografskega profila države; agrarna transformacija, aktivni srednji razred in fiskalna zmogljivost. »V primeru, da državi primanjkuje enega od štirih elementov geoekonomske moči, je takšno ne-ravnovesje nevzdržno. V končni fazi bo nesposobnost države, da se uspešno sooča s presenečenji in tveganji, razkrila njen resnični geoekonomski status« (Baru, 2012, str. 56).

Geopolitika tako postane preživet koncept, »... le še relikt zakonitosti globalne izmenjave, saj to v dobi globalizacije zamenjujejo globalne ekonomske zakonitosti, ki se kažejo kot zametki novega globalnega ekonomskega reda, ta pa presega geopolitične izračune, četudi sistemi posameznih držav ostajajo nedotaknjeni in stabilni.« (Luttwak, 1993, str. 400). Geoekonomika je nekakšno nadaljevanje logike in narave geopolitike, ki pa je v dobi globalizacije še vedno močno prisotna (Solberg Søilen, 2012, str. 8).

\section{ENERGETSKA (NE)VARNOSTV EU}

Primarna osredotočenost ukrepov EU na področju energetske varnosti je zagotavljanje zanesljive energetske oskrbe, hkrati pa zagotavljanje konkurenčnosti in dekarbonizacijo proizvodnje energije, kar posredno vodi v zmanjševanje ogljičnega odtisa v okolju. Takšno strateško razmišljanje EU po oceni Budne in Budne (2013, str. 50) vodi v gospodarski napredek in dobrobit vseh državljanov. Vendar cilji ne bodo lahko dosegljivi. Naraščanje energetske odvisnosti EU naj bi se končalo leta 2020, ko bo uvoz energije znašal okoli 56 \% celotnega uvoza. Postopen upad uvoza energije je mogoče doseči s pomočjo večje energetske učinkovitosti, še močnejšega prodora obnovljivih virov energije v evropski energetski prostor ter $\mathrm{z}$ implementacijo strategije EU 2020 (Europe's current ..., 2008, str. 19). Vse to je nujno potrebno, saj je EU v letu 2011 proizvedla samo $6 \%$ vse svetovne energije ali 805 Mtoe (milijonov ton ekvivalentne nafte), hkrati se tako količina kot delež proizvedene energije zmanjšujeta že od leta 2000 (The EU in the world 2014, 2014, str. 152). To je nedvomno posledica izčrpanih zalog energentov v Evropi in stroškovno neučinkovito izkoriščanje preostalih zalog.

7 Idejo in koncept geoekonomike pripisujejo ameriškemu vojaškemu strategu in zgodovinarju Edwardu N. Luttwaku, ki je termin geoekonomika (angl. geo-economics) prvič uporabil leta $1990 \mathrm{v}$ članku z naslovom From geopolitics to geo-economics: logic of conflict, grammar of commerce. Geoekonomika je samostojna znanstvena disciplina, ki obravnava odnose med geografijo, geopolitiko in varnostjo, hkrati pa preučuje tudi odnose med svetovnimi ekonomijami in njihove medsebojne vplive. Geoekonomika je kombinacija mednarodnih političnih in ekonomskih dejavnikov, s katerimi se lahko posredno ali neposredno vpliva na posamezno državo ali regijo. 
Preglednica 1: Bruto poraba energije EU-28 v Mtoe, po energentih (2000 in 2011) Table 1: Gross inland consumption of energy in EU-28 in 2000 and 2011 (Mtoe)

\begin{tabular}{|l|c|c|c|c|}
\cline { 2 - 5 } \multicolumn{1}{c|}{} & $\mathbf{2 0 0 0}$ & Delež (\%) & $\mathbf{2 0 1 1}$ & Delež (\%) \\
\hline EU-28 & 1724,9 & 100,0 & 1697,7 & 100,0 \\
\hline Trda goriva & 320,8 & 18,6 & 285,5 & 16,8 \\
\hline Nafta in derivati & 661,4 & 38,3 & 597,9 & 35,2 \\
\hline Zemeljski plin & 393,7 & 22,8 & 397,5 & 23,4 \\
\hline Jedrska energija & 243,8 & 14,1 & 234,0 & 13,8 \\
\hline Obnovljiva energija & 96,8 & 5,6 & 169,0 & 10,0 \\
\hline Ostalo & 8,4 & 0,6 & 13,8 & 0,8 \\
\hline
\end{tabular}

Vir/Source: The EU in the world 2014, 2014, str. 155

Neskladnost med proizvedeno in porabljeno energijo EU ter njeno strukturo je nujno potrebno osvetliti še skozi prizmo razpoložljivih zalog energijskih virov EU. Čeprav ni popolnoma transparentne in enotne metodologije ugotavljanja zalog, je mogoče ugotoviti naslednje: rezerve energijskih virov (predvsem fosilnih goriv) se v EU zmanjšujejo, čeprav so rezerve energijskih virov še vedno relativno bogate, vendar skoncentrirane v ozkem krogu držav (Resolucija Evropskega parlamenta ..., 2013). Tako British Petroleum ocenjuje, da so se zaloge nafte v EU od leta 2001 zmanjšale z 8800 mio. sodčkov na 6700 mio. sodčkov v letu 2011, kar je vsega 0,4 \% vseh svetovnih zalog nafte (BP statistical review ..., 2014, str. 4-7). Podobno je tudi pri zalogah premoga, kjer EU razpolaga s 6,5 \% vseh svetovnih zalog, vendar je od teh zalog kar $90 \%$ slabših vrst premoga (predvsem ligniti). Za primerjavo: v svetovnih zalogah je mogoče najti kar polovico kvalitetnejših premogov, kot sta antracit in bitumenski premog. Še slabše je pri zemeljskem plinu, kjer EU razpolaga z vsega slabim 1 \% svetovnih zalog: od tega je večina zalog na Nizozemskem, v Veliki Britaniji, na Poljskem, v Romuniji in Italiji (BP statistical review ..., 2014, str. 20-22).

Za države članice EU je torej značilno dvoje: zmanjševanje vseh zalog fosilnih goriv, ki že v samem začetku niso predstavljale pomembnejšega svetovnega deleža, kar vodi v drugo dejstvo - nujen uvoz energentov in posledično visoka stopnja odvisnosti od globalnih energetskih trgov. Od leta 2000 do 2006 se je uvoz energije v EU povečeval, nato je prišlo do zmanjšanja uvoza, kar je mogoče pojasniti s povečano proizvodnjo energije iz obnovljivih virov ter stabilizacijo porabe energije v EU. Kljub temu dejstvu je razkorak še vedno ogromen - medtem ko EU uvozi 1433,1 Mtoe energije, jo izvozi za 493,4 Mtoe, kar predstavlja 939,7 Mtoe energetskega deficita (podatki za leto 2011), oziroma neto uvoza energije v EU (The EU in the world 2014, 2014). 
Slika 1: Neto uvoz v EU po energijskih virih v letu 2011

Figure 1: Gross imports of energy into the EU in 2011

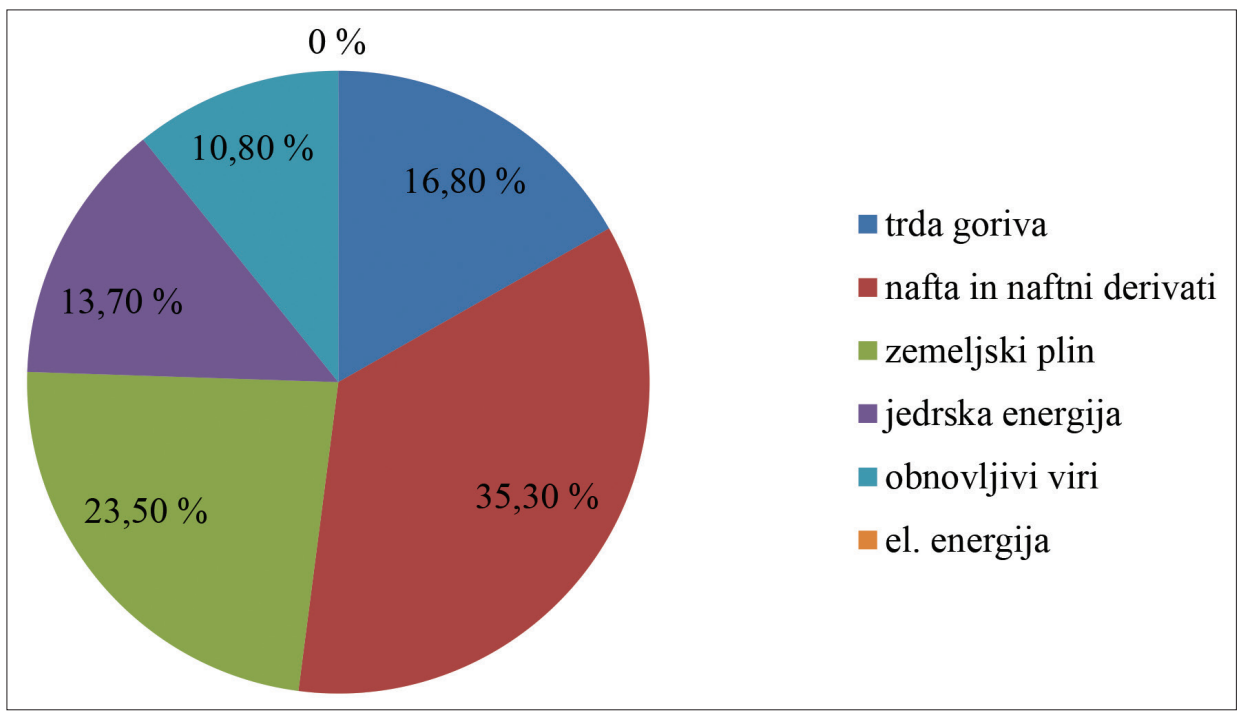

Vir/Source: The EU in the world 2014, 2014, str. 155

Zaradi predstavljenih dejstev se je energetska odvisnost EU od leta 2000 do leta 2011 povečala s $47 \%$ na $54 \%$. Kljub temu je mogoče opaziti umirjanje trenda, oziroma se napoveduje celo znižanje energetske odvisnosti. Edina energetsko neodvisna država je Danska, ki ustvari $9 \%$-ni presežek energije in je tako edina evropska neto izvoznica energije. Med najbolj energijsko odvisnimi državami so Malta (100 \%), Luksemburg (97 \%), Ciper (93\%), Irska (89\%), Litva (81\%) in Italija (81\%). Energetska odvisnost Slovenije je v letu 2012 znašala $51 \%$ (Letna energetska statistika ..., 2012). V zadnjih desetih letih je svojo energetsko odvisnost zmanjšalo 18 držav, osem držav pa jo je povečalo, med njima sta dve največji evropski gospodarstvi (Velika Britanija in Nemčija), ki prispevata največ k skupni porabi in posledično odvisnosti. Predvsem velja to za prvo, ki je bila še leta 2000 celo neto izvoznica, sedaj pa izkazuje odvisnost od uvoza v višini 36 \% (The EU in the world 2014, 2014).

\section{SKLEP}

Pri razpravah o sodobni energetski varnostni arhitekturi je mogoče jasno izpostaviti naraščajoč vpliv ali celo prevlado tega varnostnega vidika nad ostalimi, do sedaj predstavljenimi kot konvencionalnimi. Hkrati postaja vse bolj očitna tudi velika nepripravljenost držav za obvladovanje tega novega varnostnega izziva. To je morda najbolj vidno pri reševanju tega vprašanja na ravni EU, saj globalizacija energetske varnosti izkazuje potrebo po tesnem medsebojnem sodelovanju predvsem evropskih držav, ki 
ostajajo energetsko ranljive zaradi energetske nesamostojnosti in posledično odvisnosti. Vendar področja energetske varnosti ni mogoče obravnavati ločeno od nacionalnih interesov držav članic EU. Ravno obratno, zdi se, da ostaja področje energetike domena bilateralnih interesov in posledično dogovorov. Bistvenih sprememb v prihodnje ni pričakovati. Vsekakor je velik preboj v sodelovanju držav članic EU oblikovanje notranjega energetskega trga, nadgradnja energetske infrastrukture ter napredek pri zmanjševanju energetske odvisnosti EU, predvsem na račun vse večjih količin energije, pridobljenih iz obnovljivih virov. $V$ tem se skriva še neizkoriščen potencial evropskega gospodarstva in energetske varnosti. Namesto da bi prav kriza še dodatno spodbudila dodatne investicije $v$ inovativne tehnologije in posredno uveljavila smernice Evropske komisije, se dogaja ravno obratno. Cene za izpuste toplogrednih plinov so padle na vsega $3 €$ za tono, zato ta instrument posrednega financiranja novih tehnologij in posledično večje energetske varnosti ne daje več rezultatov. Države članice preusmerjajo lastne finančne vire $\mathrm{v}$ dokapitalizacije bank in neposredne spodbude nacionalnim gospodarstvom ter socialne transferje, kar bo na dolgi rok nedvomno povzročilo še večjo energetsko ranljivost, posredno pa tudi ne zagotavlja gospodarstvu stimulativnega in predvsem varnega okolja.

\section{Literatura in viri}

Agnew, J. A., 1998. Geopolitics: re-visioning world politics. London, New York, Routledge, 150 str.

Azerbajdžan odločilen za južni plinski koridor Evrope. URL: http://www.energetika.net/ novice/promet/azerbajdzan-odlocilen-za-juzni-plinski-koridor-evrope (Citirano 2. 1. 2014).

BP statistical review of world energy 2014. 2014. British Petroleum. URL: http://www. bp.com/content/dam/bp/pdf/Energy-economics/statistical-review-2014/BP-statistical-review-of-world-energy-2014-full-report.pdf (Citirano 11. 11. 2014).

Baru, S., 2012. Geo-economics and strategy. Survival: global politics and strategy, 54, 3 , str. 47-58.

Baumann, F., 2008. Energy security as multidimensional concept. München, Center for Applied Policy Research, 16 str. URL: http://www.cap.lmu.de/download/2008/CAP-Policy-Analysis-2008-01.pdf (Citirano 11. 11. 2014).

Budna, M., Budna, J., 2013. Energetska varnost Slovenije. Magistrsko delo. Ljubljana, Fakulteta za družbene vede, 246 str. URL: http://dk.fdv.uni-lj.si/magistrska_dela_2/ pdfs/mb22_budna-jasmina-metod.pdf (Citirano 11. 11. 2014).

Cohen, S. B., 2003. Geopolitics of the world system. Lanham, Rowman \& Littlefield Publishers, 435 str.

Dolman, E. C., 2002. Astropolitik: classical geopolitics in the space age. London, Portland, F. Cass, 208 str.

Europe's current and future energy position (Demand-resources-investments). Evropska komisija. 2008. URL: http://ec.europa.eu/energy/strategies/2008/doc/2008_11_ser2/ strategic_energy_review_wd_future_position2.pdf (Citirano 28. 10. 2013). 
Gazprom presenečen in razočaran nad Evropsko komisijo. 2013. RTV SLO MMC. URL: http://www.rtvslo.si/evropska-unija/gazprom-presenecen-in-razocaran-nad-evropsko-komisijo/324397 (Citirano 2. 1. 2014).

Grizold A., 1991. Nacionalno varnostni ustroj Slovenije. Teorija in praksa, 28, 7, str. 859-864.

Grizold, A., 1992. Oblikovanje slovenske nacionalne varnosti. V: Grizold, A. (ur.). Razpotja nacionalne varnosti: obramboslovne raziskave v Sloveniji. Ljubljana, Fakulteta za družbene vede, str. 59-93.

Grizold, A., 2001. Varnostna paradigma v mednarodnih odnosih. V: Luard, E. (ur). Človek, država in vojna. Ljubljana, Fakulteta za družbene vede, str. 83-161.

Kalicki, J. H., Goldwyn, D. L., 2005. The need to integrate energy and foreign policy. V: Kalicki, J. H., Goldwyn, D. L. (ur.). Energy and security: toward a new foreign policy strategy. Washington, Woodrow Wilson Center Press, str. 1-16.

Klare, M. T., 2003. Resource wars: the new landscape of global conflict. New York, H. Holt, 289 str.

Klare, M. T., 2008. Rising powers, shrinking planet: the new geopolitics of energy. New York, H. Holt, 339 str.

Letna energetska statistika, Slovenija, 2012 - začasni podatki. 2012. Ljubljana, Statistični urad RS. URL: http://www.stat.si/novica_prikazi.aspx?id=5484 (Citirano 11. 11. 2014).

Luttwak, E., 1993. The endangered American dream. New York, Simon \& Schuster, 365 str. Luttwak, E., 1999. Turbo-capitalism: winners and losers in the global economy. London, Orion Business Books, 290 str.

McNeill, J., 2001. Something new under the Sun: an environmental history of the twentieth-century world. New York, W. W. Norton \& Co, 421 str.

Müller-Kraenner, S., 2007. Energy security: re-measuring the world. Sterling (VA), London, Earthscan, 170 str.

Potencialni ukrepi evropske energetske politike. Vladni portal Slovenija - Doma v Evropi. 2013. URL: http://www.evropa.gov.si/si/energetika/ potencialni-ukrepi-evropske-energetske-politike (Citirano 21. 10. 2013).

Resolucija Evropskega parlamenta z dne 14. marca 2013 o energetskem načrtu za leto 2050, prihodnosti $\mathrm{z}$ energijo (2012/2103(INI)). URL: http://www.europarl.europa.eu/sides/getDoc.do?pubRef=-//EP//TEXT+TA+P7-TA-2013-0088+0+DO$\mathrm{C}+\mathrm{XML}+\mathrm{V} 0 / / \mathrm{SL}$ (Citirano 11. 11. 2014).

Russia's Gazprom is the world most profitable company - Forbes. URL: http://rt.com/ business/gazprom-profit-list-forbes-391 (Citirano 2. 1. 2014).

Solberg Søilen, K., 2012. Geoeconomics. London, Klaus Solberg Søilen \& Ventus Publishing ApS, 86 str.

Sovacool, B. K., 2011. Defining, measuring and exploring energy security. V: Sovacool, B. K. (ur.). The Routledge handbook of energy security. New York, Routledge, str. 1-42.

The EU in the world: a statistical portrait. 2014. Luxembourg, Eurostat Statistical Books. DOI: $10.2785 / 48181$

Yergin, D., 2011. The quest: energy, security and the remaking of the modern world. New York, Penguin Press, 804 str. 
Zgonik, S., 2013. Plinski valček. Mladina, 51-52 (20. december 2013). URL: http:// www.mladina.si/152160/plinski-valcek (Citirano 11. 11. 2014).

Žnidarič, B., 2006. Teoretična izhodišča sodobne varnostne paradigme. Delo in varnost, 51,5 , str. 53-56.

\section{NEW ENERGY SECURITY PARADIGM}

\section{Summary}

The issues of energy security in Slovenia and in the European Union in recent years have become more important, especially in the light of questions to ensure an adequate and uninterrupted supply of energy and self-sufficiency. Recent events in Ukraine and the Ukrainian-Russian conflict have re-actualized the issue of Europe's energy self-sufficiency. Again it was possible to draw conclusions that Europe is too energy dependent.

The construction of the South Stream pipeline was one of the main topics in the Slovenian media in the previous period. The project South Stream gas pipeline, which is expected to provide Russian natural gas via the Black Sea, Bulgaria, Serbia, Hungary, Slovenia and Austria to Western and Central Europe has until recently ran fairly smoothly. Slovenian desire was to reduce its energy dependence only from one source. Yet, due to legal provisions of the EU, the construction of this pipeline moves further in the future. Due to unsuccessful negotiations with potential suppliers also a competitive Nabucco pipeline project has failed. These and other facts show the extreme actuality of the energy security, which must be understood in the broader context of issues of national security, because energy supply has never been as important as it is today in the modern society. The reason for this can be found in deep energy dependence of almost all societal systems; therefore, it is not surprising that the energy consumption is on constant rise.

This paper presents security as a multidimensional concept, and taking into consideration the modern security paradigm. In fact, it is a modern multidimensional concept of safety, which is no longer confined to the military security. Energy security is an integral part of modern security concept.

The field of energy security cannot be isolated from the national interests of the EU member states. On the contrary, it seems that the energy sector remains the domain of bilateral interests and arrangements. Significant changes in the future are also not to be expected. However, a major breakthrough in cooperation between EU member states can be found in the contemplation of the EU internal market for energy, upgrading energy infrastructure and progress in reducing energy dependence of the EU, mainly due to increasing quantities of energy generated from renewable sources. Therein lays the unused potential of the European economy and energy security.

(Translated by the authors) 